Journeys towards the professionalisation of coaching: Dilemmas, dialogues and decisions along the global pathway

\author{
David E. Gray \\ Professor Management Learning \\ University of Surrey, UK
}

Published 2010 in:

Coaching: An International Journal of Theory, Research and Practice. 4(1) 4-19. 


\title{
Journeys towards the professionalisation of coaching: Dilemmas, dialogues and decisions along the global pathway
}

\begin{abstract}
The term 'profession' derives from the Latin word 'profiteor' meaning to profess. Professionalisation, is the process whereby a gainful activity moves from the status of 'occupation' to the status of 'profession'. Claims for professional status and the emergence of standards and awards are typical of the journey that occupations make (or attempt to make) towards professionalisation. However, some occupations fall short of the mark or, at best, become semi-professions with shorter training, less specialised knowledge; and more societal (state) control. If coaching is to become a profession it must adopt criteria such as the development of an agreed and unified body of knowledge, professional standards and qualifications, and codes of ethics and behaviour. While some of these are already completed or in development, the continuation of a multiplicity (and growing) number of coaching associations suggests that the pathway of coaching to professionalisation may be at best bumpy, and at worst derailed.
\end{abstract}

Keywords: coaching, professionalisation, professional standards, accreditation

\section{Introduction}

Coaching is an emerging occupation. One survey, for example, found that 32 per cent of coaches had less than two years coaching experience (ICF, 2007). According to one commentator, there are now 'legions of newly minted coaches entering the marketplace' (Lindberg, 2006:250) (although the current recession may have slowed or even temporarily reversed this trend). Expansion over recent years has brought with it a new set of dynamics, with people entering coaching from a wide range of backgrounds, including retiring executives, human resource directors, academics and management trainers, senior police officers, teachers, clinical and occupational psychologists, counsellors and psychotherapists (Bluckert, 2004). Within organisations, coaching is also provided by internal human resource development (HRD) professionals, supervisors and managers, and by external HRD and management development (MD) consultants. Hamlin et al. (2008) contend that professional coaching is substantially the same as many aspects of contemporary human resource development (HRD). This implies that the emergent field of coaching, rather than seeing itself as an independent profession, could fit within the existing and firmly established field of HRD study and practice (Hamlin et al., 2008). Indeed, as Hamlin et al. (2008) point out, professional bodies such as the American Society for Training and Development (ASTD) and the UK-based Chartered Institute of Personnel and Development (CIPD) see coaching as a core role within HRD. This article will respond to this viewpoint.

As part of, and partly in response to, the expansion of coaching has come the emergence of a growing number of coaching associations, some of which claim a professional status for coaching or an intention of achieving it. The largest of these organisations is the International Coach Federation (ICF) which has about 16,500 members, spread across 90 countries (ICF, 2009). There are now coaching associations across a range of European countries the largest being the European Mentoring and Coaching Council (EMCC) with approximately 2,700 members (Hamlin et al., 2008) and other associations such as the Association for Coaching (AC) and the Association for Professional Executive Coaching and Supervision (APECS). Most of 
these associations organise conferences, professional development events, are concerned with regulatory issues and ethics and have established systems for the credentialing of coaches.

These claims for professional status and the emergence of standards and awards are typical of the journey that occupations make (or attempt to make) towards professionalisation. Perhaps the 'time' of coaching has come. According to some scholars, coaching has now reached a greater level of maturity because coaches themselves are increasingly aware of the need to ground their practice within a sound understanding of empirically tested models (Grant and Cavanagh, 2004). Furthermore, the increased sophistication of human resource professionals (who often manage coaching programmes and have responsibility for recruiting coaches) has made them more aware of what they perceive to be pseudo-qualified coaches. Yet according to some, the industry is still in its infancy (Brennan and Prior, 2005; Prior, 2006) and a long way from meeting even the basic requirements of a true profession because it lacks a holistic theoretical framework derived from a sound empirical base and a unique body of knowledge (Vaartjes, 2005). It is also worth noting that in the USA, where the majority of the world's coaches work, the United States Labor Department does not recognise coaching as a profession (Bennett, 2006).

This article examines the concept 'professionalisation' and explores the kinds of criteria met by occupations that are typically accorded this mantle. It then evaluates the extent to which coaching currently meets these standards. In doing this, the focus will be on coaching as a developmental intervention, whether goal-oriented or personal-developmental (Ives, 2008). It does not focus on coaching as a human resource development tool, as used, say, by managers to improve performance of staff - what Peltier (2001) refers to as management coaching, using a set of day-to-day skills where managers attempt to coach rather than control. Approaches for the development of coaching as a profession are then suggested, as are routes to further research.

\section{Pathways to professionalisation}

The term 'profession' derives from the Latin word 'profiteor' meaning to profess, while professionalisation is the process whereby a gainful activity moves from the status of 'occupation' to the status of 'profession' (Emener and Cottone, 1989). Being a professional is a claim to social standing and recognition (Elliott, 1972). Bayles (1988) sets out three criteria for an occupation to claim professional status: (i) it requires extensive training; (ii) it is based upon an intellectual skill; (iii) its services are important. Hence, professionals usually earn higher incomes because their skills are in short supply and cannot be performed by others - they have a monopoly over the supply of their services (Goode, 1969). Professions usually emerge when (like coaching) there exists an effective demand for the occupational skill from a large and heterogeneous consumer group (Johnson, 1972). Even when working in an organisational bureaucracy, full professionals are able to exert autonomous decision-making - the professional acts according to his/her best professional knowledge. Established professions provide a benchmark for others to follow (Etzioni, 1969).

Professionalism, however, is a claim to status that is more or less successful within a particular social context (Shirley and Padgett, 2006). Indeed, Abbot (1988) argues that professional work is defined and redefined through the continuous struggle between different occupational groups. If successful, society (the State) grants professional groups a degree of autonomy in exchange for self-regulation - a promise that the profession will set up and enforce standards of professional development and ethical practice. This is part of what Gilmore and Williams (2007) identify as the 'social service' approach to professionalisation, with its emphasis on state intervention to create reliable standards, plus occupational training and certification, usually with 
little increase in pay or status for additional work and responsibilities. In the UK the state has allowed traditional professions such as medicine and the law to regulate their own education and training (MacDonald, 1995). This is due, in part, because professional status assumes that professional practice is orientated towards the public good rather than narrow self-interest, and that professional practice is underpinned by a legitimating body of knowledge (Shirley and Padgett, 2006).

Howard (1998), however, distinguishes between high and low roads to professionalisation. The high road is one through which genuinely effective (and proven) services are developed and made available. The low road is where an illusion of effective service is developed, in response to latent consumer demand. Historically, professions have taken the low road (Howard, 1998) claiming knowledge and skill long before they actually have it (or have been able to prove it). Before 1900, for example, the treatments offered by doctors were either completely ineffective or positively harmful (Kennedy, 1983). Furthermore, no occupation becomes a profession without a struggle (Goode, 1960), and there are many examples of occupations that have attempted to achieve professional status but have come up short of the mark. McCully and Miller (1969), for example, found that school counsellors failed to achieve this because they lacked legal recognition, professional autonomy and self-regulation.

Similarly, Rudolph (2003) asserts that, while it is a knowledge-driven service, consultancy is not a profession in the classic sense because consultants do not have a monopoly on a specific field of social problem-solving, nor do they have enforceable training regulations or recognised quality standards or rules for how they work. Consultants also have to deal with competition from the legal and accounting professions, a result of which is that consultancy has had to adopt similar professional structures and behaviour in order to be merely competitive in the marketplace (Rudolph, 2003), but without the advantages of professional status. However, the body of consulting knowledge, including methodology, have not been enough to be considered a valid and shared basis for uniform professional training, accreditation and the evaluation of competent behaviour (Visscher, 2006). Nevertheless, Bolton and Muzio (2008) note that consultancy is an example of an occupation which entertains professionalisation ambitions and hence is giving attention to selfregulation and the development of strong professional institutions. It is therefore an example of a new or aspiring profession (Goode, 1969).

Achieving professionalisation, or coming up short of the mark, however, is not a simple dichotomy, since occupations can achieve some elements of professional status while missing others. Hence, Etzioni (1969) offers the notion of semi-professionalisation with examples, in his view, being teaching, nursing and social work. Semi-profession characteristics include: shorter training, less legitimate claims to professional status; the holding of a less specialised body of knowledge; and more supervision and societal control. Teaching appears to be an 'incomplete and subordinate professional project' (Bolton and Muzio, 2008: 284), and a semi-profession, largely because of the feminisation of the workforce. Indeed, gender may be an important factor behind teaching's failure to achieve full professional status (Bolton and Muzio, 2008), contributing to lesser material rewards and lower social standing. For a semi-professional, decisions are constrained by the organisation's rules and regulations. Etzioni (1969) admits that the term 'semi' carries with it a pejorative payload, while terms such as sub-profession are hardly better.

In discussing the medical profession, Hilton and Slotnick (2005) offer the term 'protoprofession'. This is achieved through a lengthy process in which the learner develops skills, knowledge and experience needed to acquire professionalism. These though are 
merely prerequisites. What is needed for true professionalism is the kind of sophisticated reflection capable of producing phronesis (practical wisdom - insights and judgements based on the experiences arising from dealing with ill-structured problems and uncertainty). This is akin to knowledge in action (Schon, 1987), tacit knowledge (Polanyi, 1962), mindfulness (Epstein, 1999) and personal knowledge (Eraut, 1994). The example of moral development illustrates how professionalisation can occur. Proto-professions will need formal instruction on how to implement ethical principles. But only with subsequent experience and reflection will they be able to move up to full professional and principled decision-making (Hilton and Slotnick (2005).

Presented next are sets of criteria that describe the essence of being a professional, each of which is then evaluated in relation to the current professional status of coaching.

\section{Coaching and professionalisation: a critical analysis}

Coaching has reached a point where the drivers for professionalisation are coming from both coaches and from the corporate world (Bluckert, 2004). Research by PwC (2007) confirms this view, showing that 52 per cent of coaches reported that their corporate clients expect the coaches they hire to be credentialed. Bluckert (2004), however, raises concerns over the quality of coach training programmes, pointing to the growing number of poorly trained and relatively inexperienced coaches 'rolling off' two-to-five day courses. However, there are signs that this may be changing. Rostron (2009) reports on the work of the Global Convention on Coaching (GCC), established in 2007. The convention agreed an ambitious statement that affirmed 'the immediate imperative for the coaching community to come together to define and regulate itself (GCC, 2008: 4). The key recommendations of the GCC convention were that criteria should be established for levels of professional education and training, guidelines should be agreed for core competencies, and a universal code of ethics from the five codes currently available should be created. Linnecar (2009) reports on the 'Roundtable' discussions taking place between a number of coaching and related organisations (AC, APECS, the Chartered Institute for Personnel and Development, EMCC, ICF and a special group of the British Psychological Society), the aim of which is to identify strategies for taking coaching towards professionalisation.

The rest of this article examines the current status of coaching as a profession, informed by the professionalisation literature, and supported by data gathered and ideas generated within some of the coaching associations.

\section{Knowledge base}

A profession is based upon a common body of knowledge, theory, and skills that is not generally known to the public, and is based on scientific research which is unique to the profession (Dunlop, 1969; Elliott, 1972; Emener and Cottone, 1989). Ideally, knowledge and skills should be abstract and organised into a codified body of principles (Goode, 1969). A professional is someone who possesses knowledge (theoretical and practical) about a particular field, usually based upon specialised intellectual study and training (Carr-Saunders, 1966). However, as Mowbray (1995) asserts, taking the case of psychotherapy, while the acquisition of an elaborate body of knowledge may be a requirement of the typical profession, this need not necessarily be the rule for all occupations. The skill of psychotherapists lies with their ability to relate to people (as people) rather than the acquisition of, say, academic knowledge.

The power and status of professionals depend to a large extent on their claims to unique forms of expertise which are not shared by other professional groups and the value placed on that 
expertise (Eraut, 1994). The close relationship developed in the $20^{\text {th }}$ century and since between the professions and higher education has served to legitimate these knowledge claims. Indeed, universities tend to become the major centres for the production of professional knowledge (Larson, 1977). Knowledge, however, does not have to be based upon one discipline - indeed, professions tend to be quite eclectic. Accountancy, for example, draws upon law, economics, statistics and computing. However, having a broad knowledge base is a necessary but not a sufficient criterion for being a profession. Systems analysts, airline pilots and film directors have considerable skills and knowledge, but are not regarded as professions (Downie, 2000).

Coaching can be considered as an emerging cross-disciplinary occupation that embraces the behavioural sciences, business and economics, adult education (including workplace learning) and philosophy, with the behavioural sciences as possibly the key body of knowledge for coaching (Grant, 2005). To these we could add leadership and management sciences and communication techniques (GCC, 2008), because coaching (or at least business and executive coaching) is essentially about implementing and maintaining organisational change, a core focus of the behavioural sciences. Within this broad body of knowledge, Grant (2005) suggests more specialised domains from which coaches can draw: sports psychology, educational psychology, counselling and clinical psychology, health psychology and organisational psychology. The creation of an integrated knowledge-base would greatly assist the development of a unified coaching profession, but can only be achieved through the development of a common body of empirically-tested knowledge, based upon peer-reviewed research (Svaleng and Grant, 2010; Grant and Cavanagh, 2004).

Since past behaviour is often a strong indicator of potential future behaviour, psychology can make a unique contribution to coaching's knowledge base (Kemp, 2005). Sperry (2008), for example, asserts that (executive) coaching should be regarded, not as a profession in itself, but merely as a role function or identity within the profession of psychology. The GCC (2008) notes that there are tensions between coaching and psychology, partly because coaching often make extensive use of this body of knowledge. What is important is that coaches understand the boundary issues and respect regulatory frameworks of other professions, where they exist (GCC, 2008).

\section{Specialised training - programmes}

Entry to a profession requires an extensive period of specialised training in institutions of higher education (Dunlop, 1969; Elliott, 1972; Howsam, 1976; McCully and Miller, 1969; Pavalko, 1971). Competency may be assessed by examination and supervised apprenticeship or internship prior to entry to the profession. Eraut (1994) differentiates between awards offered by universities and those offered by a qualifying association for the profession. Professional colleges are of varied quality, ranging from private 'crammer' institutions (based largely on rote learning), to a training organisation set up by employers or an institution established by the profession itself (Eraut, 1994). In time, some of these colleges may seek to have their awards validated by higher education or even merge into a university, partly to improve the status of their award. However, universities will often then seek to broaden the knowledge base, and to challenge longestablished professional practices (Eraut, 1994). According to Goode (1969) occupations aspiring to become professions, must ensure that their trainees learn as much as trainees in the recognised professions. Professionalisation, however, does not just require specialised training. A characteristic of professionalism is that professionals, once fully qualified, engage in learning or training as part of what is now termed continuing professional development.

In the case of coaching, the last 20 years has seen the emergence of a number of coaching 
associations, many of which offer accreditation. According to Laff (2007), the certification of coaches is a process that lends credibility to the field and helps customers distinguish between levels of experience. Professional standards are being raised, so 'the profession is demanding its practitioners prove they can do what they say' (Laff, 2007: 39). The International Coach Federation (ICF), for example, founded in 1995 in the USA but now a global organisation, sees itself to be the voice of the coaching profession, with its core purpose seen as advancing the art, science and practice of professional coaching. The ICF offers three levels of certification, the most advanced, the Master Certified Coach, requiring a minimum of 2,500 hours of coaching experience with at least 35 clients. 6,000 coaches have passed through ICF programmes in the last 10 years - about 36 per cent of its current membership. The proposal to move to one level of qualification (one that meets ISO standards) has caused a passionate debate (for and against) amongst the ICF membership (Linkedln, 2010).

However, the ICF is not the only coaching association in the field. The Association for Coaching (AC), founded in 2002, sees itself as a leading professional body with the aim of promoting best practice and raising standards and awareness across the coaching industry (AC, 2009). Similarly, founded in 2003, the International Association of Coaches seeks to advance coaching standards by offering certification and promoting ethical principles, while the Association for Professional Executive Coaching and Supervision, founded in 2005, sees itself as the top level professional body (my emphasis) for the accreditation of executive coaches and the supervisors of coaches (APECS, 2009). Then there is the European Mentoring and Coaching Council (EMCC) whose aims are: to promote good practice and the expectation of good practice in mentoring and coaching across Europe, an aim that the EMCC promotes through its quality standards and awards (EMCC, 2009). The purpose of these standards is to support the 'professionalisation of the coaching and mentoring industry' (Willis, 2009) by allowing coaching (and mentoring) training organisations to benchmark their programmes against the standards. This is an approach that Eraut (1994) designates as the creation of a knowledge base via working professionals. He warns, however, that higher education has a strong personal interest in the sale and production of knowledge and user-derived standards threaten this hegemony.

It is not surprising, then, that the GCC (2008) notes the great diversity of programmes across the world. A few countries (for example, the USA, the UK, Australia, Canada, Argentina and Spain) have programmes offered at higher education level, most of which focus on life, executive or business coaching. The University of Sydney, for example, was the first university to offer an MA in Coaching Psychology, launching the programme in 2000. The proliferation of academic programmes in coaching parallels the path taken by clinical psychology, and includes programmes offered by some of the better-known US universities (Williams, 2006). In most other countries, however, programmes are offered by private training organisations, through one of the coaching associations or their affiliated (non-academic) coaching institutes. There are many self-proclaimed accrediting organisations (GCC, 2008). What is essential is that guidelines are established for the design and development of coaching programmes. Furthermore, as the GCC (2008) recommends, educators should be accountable through third-party evaluation. Although private providers may be suitable for skills training, for coaching to remain self-regulated, it must have partnerships with academic institutions which can provide research, applied theory and quality skills acquisition (Williams, 2006).

\section{Specialised training - supervision}

Supervision is not a developmental intervention in all professions, but it is an essential part of occupations close to coaching - counselling and psychotherapy. The British Association for 
Counselling and Psychotherapy, for example, sees supervision as essential for monitoring and reviewing the therapist's work as part of maintaining good practice (BACP, 2010). Supervision is beneficial because it assessed the extent to which the coach meets the needs of the client, promotes reflection on practice, develops new approaches and learning and ensures high ethical standards (SGCP, 2007) and the sharing of expertise (Bachkirova, Stevens and Willis (2005). It also offers a dynamic process through which the coach is encouraged to maintain a degree of awareness of the impact they have on the client at both a surface and deep level (Gray, 2010). Even when the focus is ostensibly on business themes, personal, experiential and problembased issues often arise during the coaching process - including 'red flag' situations when the coachee may be experiencing psychological discomfort (Gray, 2007).

Carroll (1996) distinguishes between training supervision, in which someone undergoes initial professional development for one of the helping professions, and consultative supervision, an arrangement between two qualified persons where one helps the other to reflect on their professional practice (a kind of co-supervision). Trainee supervision, then, may include (or even require) an element of overseeing and assessment - as well as collaboration. The supervision of qualified practitioners is more likely to contain a collaborative element.

Supervision is recommended by some of the coaching associations, and a study by Hawkins and Schwenk (2006) found that 88 per cent of coaches believe that they should have continuous and regular supervision. However, research by the Association for Coaching (2007) found that just under half of the respondents had a supervisor, whilst a third had some kind of arrangement such as peer supervision. This means that about a third of coaches fail to engage with supervision of any kind. The reasons given for this included cost and a lack of trained and experienced supervisors available. A further problem is that while the organisations that hire coaches believe that supervision is important, they are unsure as to what forms that supervision should take (Hawkins and Schwenk, 2006). What is clear is that coaches often work in and for organisations, and it is the organisation that sets the coaching agenda, particularly if they are sponsoring the coaching intervention (Carroll, 2006). The supervisor's role becomes one of handling the tensions between the coach, the coachee and their organisation (Paisley, 2006) and coping with complex dynamics of maintaining professional boundaries, managing contracts and being aware of the needs and responsibilities of each player (Carroll, 2006).

A model of coach supervision (adapted for coaching from counselling and psychotherapeutic models) is proposed by Gray (2007). The model, aims to assist in the professional development of coaches through: a contracting process, a focus on the supervisory relationship, and a discussion of teaching methods that include direct instruction, self-reflection, modelling (of good professional practice, including ethical practice) and providing feedback. A key question revolves around the role of the supervisor in the professional development and assessment of the coach's competence to practice. What, for example, should be the relationship, if any, between the supervisor, and the coach's training institution? How formal should the assessment role of the supervisor be? Another issue relates to the issue of matching supervisor and coach. Should both hold similar theoretical models of coaching? Should the models used and training undertaken by the supervisor be based within psychology? What level or kind of professional development should supervisors hold? How should supervisors be trained? How should they be accredited? Hence, there are questions to be resolved not just about the professionalisation of coaches, but also of coach supervisors.

\section{Independence and autonomy}

Individual members of the profession possess broad authority over the practice of their services 
and the profession as a whole possess broad autonomy over internal operations (Dunlop, 1969; Elliott, 1972; Howsam, 1976). A profession must be independent to fulfil its role and be seen to be independent (Schein, 1972). Professional autonomy, however, is always constrained. License to practice is only granted on the basis of demonstrated competence is conditional, and can grow or be curtailed over time (Hoyle and John, 1995). One of the keys that identify a profession is the control members have over the technical aspects of their work. Society, however, will only grant autonomy to a profession and an effective monopoly, when it has persuasively demonstrated that it is sole master of its special craft - and that its decisions are not to be reviewed or challenged by other professions. The most severe skirmishes are likely to occur between a new profession and the occupations closest to it in terms of client interest (Goode, 1960). Weight also has to be given to the views of consumers of professional services, particularly their views as to the quality of the service they receive. If a profession fails to regulate itself, or if its regulatory measures are deemed to be insufficient, the state may step in and impose its own regulatory framework.

Some of the coaching associations have been conscious of the need to maintain the autonomy of coaching through a self-regulatory oversight by tracking the concerns of individuals and organisational clients on an international basis (ICF, 2005). The ICF, for example, set up a regulatory committee in 2002 the remit of which was to research, monitor, evaluate and contribute to government regulatory bodies, primarily in the USA and Canada. This, though, has not prevented cases such as the Colorado Mental Health Board. Here, a member of the Board questioned whether coaching, and especially personal coaching, should be regarded as equivalent to psychotherapy, and so all coaches should be registered as unlicensed psychotherapists. Only intense lobbying by the ICF and allied coaching associations gained an amendment to the state legislation exempting coaching from the state's oversight (Williams, 2010).

It appears, however, that to some extent, the existence of an association like the ICF, with its code of ethics, has given some surety to state legislators that self-regulation is taking place (Williams and Anderson, 2006) and that state regulation is unnecessary. However, the fact that several US states have considered the regulation of coaching, suggests that continuing selfregulation is not guaranteed. Similarly, in the UK, the work of practitioner psychologists (including clinical psychologists and counselling psychologists) is now regulated by the Health Professions Council (HPC) which maintains a register of 200,000 health professionals from 14 professions. Interestingly, the group 'psychotherapists and counsellors' are not currently regulated under the HPC, but their future regulation was recommended in the 2007 White Paper and the HPC has established a liaison group to examine their case (HPC, 2009). It seems likely, then, that all the various counselling and psychotherapy associations in the UK will soon come under the one state regulator, at least as far as registration is concerned. It is a matter of conjecture whether coaching will be far behind. Such a move, however, may not be viewed negatively by all coaches. A survey conducted amongst over 5,000 ICF members (PwC, 2007) found that most agreed that the industry should be regulated in some form in the future. However, this view ranked in the top three overall in terms of disagreement by some respondents. Generally, European coaches were significantly more favourable towards regulation of the industry (73 per cent) than the overall global response (65 per cent). Some of the implications of such regulation are worth noting. As Mook (2007) comments, regulation may complicate arrangements for cross-cultural coaching, where the coach resides in a non-regulated country, but the coachee's country of residence is regulated.

\section{Service relationship}


The ideal of service is that the solution the professional arrives at, are based on the client's needs and not the material interests of the professional him or herself. Indeed, the occupation will be classified as less professional if the client imposes their own judgement (Goode, 1969). A profession provides this service, via a relationship. Downie et al (1974) define a relationship as a bond, and the sets of attitudes that link two people. In psychotherapy, the aim of wanting to improve behaviour or how people feel, is based on an intense, confidential relationship, based on respect and a wish to be of help. It is a relationship, however, that is influenced by the boundaries set by ethical frameworks (see below). This is because the service relationship requires a professional attitude, one that recognises the vulnerability of the client, and the potential for unequal power.

Coaching is service orientated, a service based upon the coach's ability to form a close personal connection with the coachee (Wasylyshyn, 2003). The coach must not only understand the coachee's problems - they must communicate genuine empathy with them (Peltier, 2001), as well as establishing rapport. However, coaches (including coaches trained as psychotherapists or counsellors) need to remain aware that coaching may deal with the client's emotions but is not a therapeutic intervention. Boundaries between coaching and psychotherapeutic interventions have to be maintained. Indeed, as Hamlin et al. (2008) argue, the services that coaches provide do not necessarily have to be based upon psychology - they can be based upon human resource development practice in its widest sense, including facilitating cultural and organisational change.

\section{Professional commitment}

Members of a profession possess a strong commitment to the profession (McCully and Miller, 1969; Howsam, 1976), and strongly identify with the profession and are affiliated to it - indeed, they see themselves as 'tied' to the profession, a high percentage of members remaining in the profession throughout their lifetime (Goode, 1969; Ekstein and Wallerstien, 1958). Professionals derive pleasure and pride from the status which their function affords them in their community. This psychological amalgamation between the person and their function is one of the products of professional training, one result of which is that those within the occupation see it as distinct from similar occupations. For professionals, the nature of their work becomes part of their life (Ekstein and Wallerstien, 1958) and their self-identity.

Coaching, however, is often delivered by organisations for whom this service is intermixed with other services, or offered as a sideline. Researching the Australian market, Clegg et al. (2005) found that few coaching providers focus exclusively on coaching, with two-thirds of respondents offering two or three other products, including consulting, training and development and the training of coaches. Indeed, much of what is claimed as professional coaching in the USA, the UK and Australia is, in fact, delivered by external consultants (Hamlin et al. 2008). Pennington's (2009) survey of 1800 coaches, worldwide, found that respondents spent 41 per cent of their time on executive coaching, and 25 per cent of their time on other coaching (e.g., life coaching) but the remainder on other activities. These included training facilitation, teaching, consulting, meditation and counselling. The scale of professional commitment as a coach then, will be partly determined by the extent to which coaching is the prime service offered by the individual, and the extent to which the coach has been socialised into the coaching profession through training and supervision.

\section{Enforcement of ethical codes}

Members of a profession are bound by ethical codes that define both ethical and unethical 
conduct and the professional association provides for strict reinforcement of its rules (Dunlop, 1969; Elliott, 1972; McCully and Miller, 1969). Breaches of an ethical code, in principle, can lead to disciplinary action which may include expulsion from the profession. However, according to Mowbray (1995) disciplinary enforcement is often weak and does little to deter transgressions. Others view ethical frameworks as useless and oppressive in actual day-to-day decision making processes. Professionals encountering an ethical dilemma, for example, do not go to their office, shut the door, take a copy of their relevant ethical code off the shelf, and look up the best course of action. What they need is the opportunity to engage in dialogue with fellow professionals, a 'resolving conversation' that allows them to consider what they are overlooking and to test out possible outcomes in a non-judgemental atmosphere (Rossiter, Walsh-Bowers and Prilleltensky, 1996).

Worldwide there are no enforceable ethical codes for coaching practice (Svaleng and Grant, 2010). While sets of ethical codes of conduct are laid down by most of the coaching associations, they are similar, but by no means identical, in content. The EMCC code requires that coaches ensure that their level of competence is sufficient to meet the needs of the client, that they understand the context in which the coaching is taking place, are aware of potential conflicts of interest and boundary issues, that they maintain confidentiality and work professionally in not exploiting the client, including for financial or sexual gain. The ICF code contains similar requirements, and stresses the need for coaches to avoid conflicts of interest and to have clear contracts with their clients and sponsor. The Association for Coaching's code makes specific reference to the need of coaches to refer clients on to more experienced coaches, to general practitioners, counsellors, psychotherapists or other specialist services, in cases where their own skills fall short of those required. There is a basis, then, for synthesising and rationalising all the various codes into a unified structure, taking 'best practice' from each. This, however, may be a necessary but insufficient step. As the GCC (2008) states, coaches also need education in how to cope with real ethical dilemmas. As noted earlier, ethics cannot be applied by merely reading a book. What is required in an opportunity to discuss issues with fellow professionals in a non-judgemental atmosphere (Rossiter, et al., 1996). The coaching associations, then, should consider encouraging more debate on ethical issues (particularly dilemmas) at their conferences and professional development events. Compulsory supervision would also give coaches access to an experienced expert who, if skilled, can act as a role model in addressing ethical dilemmas.

\section{Discussion and Recommendations}

The analysis above, suggests that coaching has made some important steps towards professionalisation. It is service-oriented like most professions and is an occupation which has attracted large numbers of enthusiastic new entrants (evidenced by the growth in membership of the various coaching associations). The move towards professionalisation is also supported by the emergence of coaching qualifications and frameworks for accreditation and (usually where linked to higher education) quality assurance of such qualifications. Yet, despite these positive developments, a number of fundamental challenges remain.

One is the fragmentation of the industry into rival coaching associations, each competing to offer different types and levels of qualification. Although, as we have seen, there is evidence of discussion about common standards and approaches, there needs to be more evidence of a unified strategy and tangible collaborative outcomes. It is recommended that the associations work together to:

- Develop a common global policy framework for assessment and certification (including 
standards, levels and knowledge-base), recognising that this may have to be modified to fit with regional or national needs. Develop processes, and implementation strategies, for third-party validation and quality assurance of accredited coaching programmes. Use institutions of further or higher education for this purpose, unless there are sound reasons for doing otherwise.

- Make supervision a requirement of coaching association membership. Encourage supervision at both initial training and continual professional development phases. Develop a competency framework and training standards for coach supervisors, from which new training programmes can develop.

- Establish a global observatory to monitor the efforts of national, regional or federal states to regulate coaching, and develop policy responses for improving coaching selfregulation. Monitor and publicise the attitudes of association members towards selfregulation versus state regulation. In national contexts where approved by their membership, facilitate the move of coaching towards national or federal state regulation.

- Develop a global, unified, code of ethics, and promote policies and strategies to ensure that training programmes are created that provide formal instruction (and informal dialogue) on how to implement ethical codes.

- Facilitate, sponsor and assist the development of evidence-based research (in fields including organisational development, psychology, management theory and human resource theory) that will serve to enhance the credibility and further the legitimacy of coaching's knowledge-base.

- Promote the existence and quality of coaching standards, training and accreditation frameworks across potential markets. Work to distinguish coaching from other helping professions. Educate the client.

- Explore strategic alliances with other helping professions such as psychology, psychotherapy and human resource professionals.

Given that coaching is normally taken up after an initial professional career, coaching programmes could include measures for the accreditation of prior certificated learning, so that prior (relevant) professional and academic qualifications can be counted towards the coaching qualification. Similarly, in line with work-based learning principles (Raelin, 2000; Gray et al, 2004), experiential learning (in coaching or related areas) could be documented (typically through a portfolio of evidence), assessed and awarded credits. This approach deserves further exploration by those coaching associations offering certification.

A remaining issue is the relationship between coaching and human resource development, particularly Hamlin et al's (2008) suggestion that coaching becomes just an integral part of professional practice within HRD. A coach, then, might study for an HRD qualification which might include coaching as an option or module. This has the advantage of integrating coaching into a well established profession, at least as far as the UK is concerned. However, coaching is practiced more widely than just within $\mathrm{HR}$, and this route would fail to recognise the distinctiveness of coaching as a service and intervention. But, as stated above, coaching should seek strategic alliances and collaboration with HR where opportunities arise.

A number of questions arise which are recommended for further research. What is the attitude of 
coaches towards professionalisation? To what extent do they value, or disapprove of, the prospect of higher level qualifications and the resulting limits on entrants to the industry? As Grant and Cavanagh (2004) argue, creating a profession means making decisions about who will be 'in' and who will be 'out', based upon defined levels of skills and knowledge. What is the attitude of clients (business and personal) to coaching professionalisation? What benefits, if any, do they perceive this as bringing? What about psychologists? What value, if any, do they see in adding coaching to their current qualifications? Either way, some of these questions may be overtaken by events. In the USA and UK, at least, the state is seeking much greater control and regulation of the health-related professions. Whether coaching finds itself pulled into the regulation vortex, will depend much on its perceived status, political influence, and the attitude (beneficent or otherwise) of coaching's closely related professional partners. 


\section{References}

Abbot, A. (1988) The System of Professions. Chicago: University of Chicago Press.

Association for Coaching at: http://www.associationforcoaching.com/home/ (Accessed 2 July, 2009).

Association for Professional Executive Coaching and Supervision (2009) at: http://www.apecs.org/ (Accessed 2 July 2009).

Backkirova, T., Stevens, P., and Willis, P. (2005) Coaching supervision. Oxford: Oxford Brookes, Coaching and Mentoring Society.

Bayles, M.D. (1988) 'The professional-client relationship', In J.C. Callahan (ed) Ethical Issues in Professional Life. Oxford: Oxford University Press.

Bennett, J.L. (2006) 'An Agenda for Coaching-Related Research: A Challenge for Researchers. Consulting Psychology Journal: Practice and Research 58(4) 240-249.

Bluckert, P. (2004) 'The state of play in corporate coaching: current and future trends'. Industrial and Commercial Training 36(2) 53-56.

Bolton, S. and Muzio, D. (2008) 'The paradoxical processes of feminization in the professions: the case of established, aspiring and semi-professions'. Work, employment and society. 22(2) 281-299.

Brennan, D. and Prior, D.M. (2005) 'The Future of Coaching as a Profession: The Next 5 Years (2005-10)'. http://www.coachfederation.org/ Accessed 21 May, 2010.

British Association for Counselling and Psychotherapy (2010) Code of Ethics and Practice for the Supervision of Counsellors, (http://www.bacp.co.uk/prof_conduct/public_code_supervision.htm). Accessed 23 March 2010.

Carr-Saunders, A.M. (1966) 'Professionalisation in Historic Perspective'. In H.M. Vollmer and D.L. Mills (eds) Professionalisation Englewood Cliffs, New Jersey: Prentice-Hall.

Carroll, M. (1996) Counselling Supervision: Theory, Skills and Practice. London: Cassell.

Carroll, M. (2006) 'Supervising executive coaches’ Therapy Today 17(5).

Clegg, S.R., Rhodes, C., Kornberger, M. and Stilin, R. (2005) 'Business coaching: Challenges for an emerging industry.' Industry and Commercial Training, 37(5) 218-223.

Downie, R.S. (1990) Professions and Professionalism Journal of Philosophy of Education 24(2) 147-159.

Downie, R.S., Loudfoot, E. \& Telfer, E. (1974) Education and Personal Relationships. London: Methuen.

Ekstein, R. and Wallerstein, R. (1958) 'Professional Identity of the Psychotherapist'. In R. Ekstein and R. Wallerstein, The Teaching of Psychotherapy. NY: Basic Books. 
Elliott, P. (1972) The Sociology of the Professions. London: MacMillan.

EMCC (2009) at: http://www.emccouncil.org/ Accessed 10 July.

Emner, W.G. and Cottone, R.R. (1989) 'Professionalisation, Deprofessionalisation, and Reprofessionalisation of Rehabilitation Counseling According to Criteria of Professions. Journal of Counseling and Development. 67, 576-581.

Epstein, R.M. (1999) 'Mindful practice'. JAMA 282 (9) 833-39.

Eraut, M. (1994) Developing Professional Knowledge and Competence. Oxford: RoutledgeFalmer.

Etzioni, A. (ed) (1969) The Semi-Professionals and Their Organization: Teachers, Nurses and Social Workers. London: Collier-Macmillan Ltd.

Gilmore, S.E. and Williams, S. (2007) 'Conceptualising the 'Personnel Professional': a Critical Analysis of the Chartered Institute of Personnel and Development's Professional Qualification Scheme'. Personnel Review, Vol. 36 (4).

Global Coaching Community (GCC), (2008) Dublin declaration on coaching. Global Convention on Coaching, Dublin: GCC. Retrieved 10 March, 2010 from: http://www.pdf.net/Files/Dublin\%20Declaration\%20on\%20Coaching.pdf

Goode, W.J. (1960) 'Encroachment, charlatanism, and the emerging profession: psychology, sociology and medicine'. American Sociological Review, 25(6) 902-965.

Goode, W.J. (1969) 'The Theoretical Limits of Professionalisation.' In A. Etzioni (ed) The SemiProfessions and their Organizations. New York: The Free Press.

Grant, A.M. (2001) Towards a psychology of coaching. Coaching Psychology Unit, School of Psychology, University of Sydney. http://www.psych.usyd.edu.au/psychcoach/Coaching_review_AMG2001.pdf (Accessed 3 October, 2009).

Grant, A.M. (2005) 'What is Evidence-Based Executive, Workplace and Life Coaching?' Evidence-based coaching: Theory, research and practice from the behavioural sciences Vol 1: 1-12.

Grant, A.M. and Cavanagh, M.J. (2004) 'Toward a profession of coaching: Sixty-five years of progress and challenges for the future'. International Journal of Evidence-based Coaching and Mentoring 2(1) 1-16.

Gray, D.E. (1996) 'The Deprofessionalisation of Initial Teacher Training' 1st Conference on PanEuropean Collaboration Projects in Teacher Education, 2-4 July, Cesky Krumlov, Czech Republic

Gray, D.E. (2007) 'Towards a systemic model of coaching supervision - some lessons from psychotherapeutic and counselling models'. Australian Psychologist. 42(4) 300-309.

Gray, D.E. (2009) Doing Research in the Real World. (2nd ed.) London: Sage.

Gray, D.E. (2010) Towards the lifelong skills and business development of coaches: an integrated model of supervision and mentoring. Coaching: An International Journal of 
Theory, Research and Practice 3(1) 60-72.

Gray, D.E., Cundell, S., Hay, D. and O'Neill, J. (2004) Learning through the Workplace. Cheltenham: Stanley Thornes.

Hamlin, R.G., Ellinger, A.D. and Beattie, R.S. (2008) 'The emergent 'coaching industry': a wakeup call for HRD professionals'. Human Resource Development International 11(3) 287305.

Hawkins, P. and Schwenk, G. (2006) Coaching Supervision: A Paper Prepared for the CIPD Coaching Conference London: CIPD.

Howard, A. (1998) 'Roads to professionalisation: Dare we travel the 'integrity route'? British Journal of Guidance \& Counselling, 26(2) 303-309.

Hoyle, E. and John, P.D. (1995) Professional Knowledge and Professional Practice. London: Cassell.

HMSO (2007) Trust, Assurance and Safety - The Regulation of Health Professionals in the 21st Century. London: HMSO.

Health Professions Council (2009) at: http://www.hpc-uk.org/ Accessed 10 July, 2009.

Hilton, S.R. and Slotnick, H.B. (2005) 'Proto-professionalism: how professionalisation occurs across the continuum of medical education'. Medical Education 39 58-65.

International Coach Federation (2005) Coaching Professionalism, the ICF, and You. Regulatory Committee of the ICF, co-chairs Dianne Brennan and Patrick Williams.

International Coach Federation (2007) ICF Global Coaching Study. Lexington, KY: International Coach Federation.

International Coach Federation (ICF) (2009) http://www.coachfederation.org/ (Accessed 2 October 2009).

Ives, Y. (2008) 'What is 'Coaching'? An Exploration of Conflicting Paradigms'. International Journal of Evidence-Based Coaching and Mentoring. 6(2) 100-113.

Johnson, T.J. (1972) Professions and Power. London: The MacMillan Press.

Kemp, T.J. (2005) 'Psychology's Unique Contribution to Solution-Focused Coaching: Exploring Clients' Past to Inform Their Present and Design Their Future'. Evidence-based coaching: Theory, research and practice from the behavioural sciences Vol 1: 37-47.

Kennedy, I. (1983) The unmasking of medicine. London: Paladin.

Laff, M. (2007) 'The certified coach: a brand that should be trusted'. T+D (April) 39-41.

Larson, M.S. (1977) The Rise of Professionalism: A Sociological Analysis. Berkley, CA: University of California Press.

Lindberg, W.H. (2006) 'Thoughts on the Future of Coaching and Coach Training' In P. Williams and S.K. Anderson Law \& Ethics in Coaching. New Jersey: John Wiley \& Sons. 
Linkedln (2010) online discussion 'ICF proposes to move to ONE credential'. Accessed 26 February.

Linnecar, R. (2009) Evolution of a Coaching Profession. Discussion document shared with the author.

MacDonald, K.M. (1995) The Sociology of the Professions. London: Sage.

Mowbray, R. (1995) The Case Against Psychotherapy Registration. London: Trans Marginal Press.

Mowbray, R. (1997) Too vulnerable to choose. In R. House and N. Totton (eds) Implausible Professions: Arguments for Pluralism and Autonomy in Psychotherapy and Counselling. Ross-on-Wye: PCCS Books.

McCully, C.H. and Miller, L.L. (1969) Challenges for change in counsellor education. Minneapolis, MN: Burgess Publishing Co.

Mook, M.N. (2007) 'Does Coaching Need Regulation or Recognition?' EMCC Conference, Stockholm. 11-13 October.

Peltier, B. (2001) The Psychology of Executive Coaching. London: Brunner-Routledge,.

Pennington, W. (2009) Executive Coaching World: A Global Perspective. Chi Press. Online at: www.chiteaching.com.

Polanyi, M. (1962) Personal Knowledge: Towards a Post-critical Philosophy. Chicago: University of Chicago Press.

Prior, D.M. (2006) 'Professional Coaching Language for Greater Public Understanding'. In P. Williams and S.K. Anderson Law \& Ethics in Coaching. New Jersey: John Wiley \& Sons.

PwC (2007) ICF Global Coaching Study. Lexington, KY: International Coach Federation.

Raelin, J.A. (2000), Work-Based Learning: The New Frontier of Management Development, New Jersey: Prentice Hall

Rogers, C. (1961) On becoming a person. Houghton Mifflin, Boston: MA.

Rossiter, A., Walsh-Bowers, R. and Prilleltensky, I. (1996) 'Learning From Broken Rules: Individualism, Bureaucracy, and Ethics'. Ethics and Behavior 6(4) 307-320.

Rudolph, H. (2003) 'Women in business consultancies: chances or risks of professionalisation?' $6^{\text {th }}$ European Sociology Association, Research Networks 15, Sociology of Professions, Murcia, September 23-26.

Schein, E.H. (1970) Professional Education: Some New Directions New York: McGraw-Hill.

Schon, D.A. (1987) Educating the Reflective Practitioner. San Francisco: Jossey-Bass.

Shirley, J.L., and Padgett, S.M. (2006) 'An Analysis of the Discourses of Professionalism' In Wear, D. and Aultman, J.M. Professionalism in Medicine: Critical Perspectives. New York: Springer. 
Special Group in Coaching Psychology. (2007). Guidelines on supervision for coaching. London: The British Psychological Society.

Sperry, L. (2008) Executive Coaching: An Intervention, Role Function, or Profession? Consulting Psychology Journal: Practice and Research 60(1) 33-37.

Svaleng, I.L.J. and Grant, A.M. (2010) 'Lessons from the Norwegian coaching industry's attempt to develop joint coaching standards: An ACCESS pathway to a mature coaching industry'. The Coaching Psychologist 6(1) 5-15.

Vaartjes, V. (2005) 'Integrating action learning practices into executive coaching to enhance business results'. International Journal of Evidence Based Coaching and Mentoring 3(1) 117.

Visscher, K. (2006) 'Capturing the competence of management consulting work.' Journal of Workplace Learning 18(4) 248-260.

Wasylyshyn, K.M. (2003) 'Executive coaching: an outcome study'. Consulting Psychology Journal: Practice and Research 55(2) 94-106.

Williams, P. (2010) The coaching profession grows up. Accessed at: http://www.lifecoachtraining.com/resources/articles/articles/coaching_grows_up.pdf 2 December.

Williams, P. (2006) 'The Emergence of Academic Degrees in Personal and Professional Coaching: What Does this Mean to the Future of Coaching? In P. Williams and S.K. Anderson Law \& Ethics in Coaching. New Jersey: John Wiley \& Sons.

Williams, P. and Anderson, S.K. (2006) Law \& Ethics in Coaching. New Jersey: John Wiley \& Sons.

Willis, P. (2009) 'New phase of EMCC standards research announced'. Training Reference. Accessed at: http://www.trainingreference.co.uk/news/co050124.htm 14 September. 